\title{
A comparison of soil tests to predict the growth and nodulation of subterranean clover in aluminium-toxic topsoils
}

\author{
M.G. WHITTEN and G.S.P. RITCHIE
}

\begin{abstract}
Total $\mathrm{Al}$ concentration or $\mathrm{pH}$ in $1: 510 \mathrm{~m} M \mathrm{CaCl}_{2}$ extracts and exchangeable $\mathrm{Al}$ in $100 \mathrm{~m} M \mathrm{BaCl}_{2}$ extracts cannot always distinguish between Al-toxic and Al-nontoxic topsoils. Our objectives were to compare the abilities of different measures of $\mathrm{Al}$ and $\mathrm{pH}$ in various extracts to predict the effects of acidity on growth and nodulation of subterranean clover. In a glasshouse experiment, Trifolium subterraneum L. cv. Mt Barker was grown in acidic soils from 3 sites in the Western Australian wheatbelt with different histories of phosphate fertilizer application. The $\mathrm{pH}$ was adjusted to give a range of 3.8-7 in the centrifuged soil solution (SS). Total (Al-tot), reactive Al (8-hydroxyquinolineextractable, $\mathrm{Al}-\mathrm{HQ}$ ) and $\mathrm{pH}$ were measured in $\mathrm{SS}$ and $1: 5$ extracts of $\mathrm{KCl}, \mathrm{CaCl}_{2}$ and $\mathrm{LaCl}_{3}$. Another method of estimating reactive $\mathrm{Al}(\mathrm{Al}$ which reacts with Chelex-100) was also measured in SS only. Other measurements included exchangeable $\mathrm{Al}$ and $\mathrm{H}, \mathrm{Ca}$ in $\mathrm{SS}$, and $\mathrm{P}$ in $\mathrm{SS}$ and the $\mathrm{CaCl}_{2}$ extracts. Both plant growth and early nodulation decreased with increasing acidity. Plant growth in the acidified and unlimed treatments of all soils was best described by Al-HQ in SS, $\mathrm{KCl}$ or $\mathrm{CaCl}_{2}\left(\mathrm{r}^{2}=0.68-0.70\right)$. Multiple regression of relative yield against $\mathrm{Al}$ or $\mathrm{pH}$ with the concentration of $\mathrm{P}$ in SS increased the percentage variation explained by $10 \%$ and $30 \%$, respectively. Early nodulation was well correlated $\left(r^{2}=0.67-0.91\right)$ with $\mathrm{pH}$ or exch. H, Al-tot or exch. Al and Al-HQ. No improvement in the correlation was gained by including $\mathrm{P}$ using multiple regression. At constant ionic strength, increasing the valence of the extracting cation decreased the ability of soil tests to distinguish phytotoxic $\mathrm{Al}$.
\end{abstract}

\section{Introduction}

Al toxicity can affect productivity in a farming system both directly by decreasing yield of sensitive crop and pasture species and indirectly by decreasing the amount of $\mathrm{N}$ supplied to crops grown in rotation with Al-sensitive legumes. The importance to agriculture of identifying $\mathrm{Al}$ problems in soils with low $\mathrm{pH}$-buffering capacities lies in the high costs of applying lime relative to returns over the short term. So far, no soil test has proven capable of predicting Al toxicity.
In acidic conditions, decreased growth of subterranean clover can be due to $\mathrm{Al}$ toxicity directly affecting plant growth (Munns, 1965) and/or to poor nodulation limiting nitrogen fixation (Coventry and Evans, 1989). Decreased nodulation and damage to root hairs are observed at concentrations of monomeric $\mathrm{Al}$ as low as $6.4 \mu M$ (Kim et al., 1985a) as determined by the 30-min aluminon method (Blamey et al., 1983).

In simplified acid solutions with careful control of $\mathrm{pH}$, ionic strength and concentration of ligands forming complexes with $\mathrm{Al}$, it has been 
possible to demonstrate that decreased plant growth is well correlated with the activity of the $\mathrm{Al}^{3+}$ ion (henceforth denoted $\left(\mathrm{Al}^{3+}\right)$, Cameron et al., 1986) or the sum of the activities of inorganic monomeric $\mathrm{Al}$ species $\left(\Sigma\left(\mathrm{Al}_{\text {mono }}\right)\right.$, Blamey et al., 1983). In complete nutrient solutions and soils, calculation of speciation of $\mathrm{Al}$ is not possible because there are no thermodynamic data available for $\mathrm{Al}$ complexes with phosphate or fulvic and humic acids.

Wright et al. (1987) attempted to simplify the speciation calculations by using the concentration of reactive $\mathrm{Al}$ in the soil solution of subsoils as determined with three colorimetric methods to estimate $\Sigma\left(\mathrm{Al}_{\text {mono }}\right)$ from which $\left(\mathrm{Al}^{3+}\right)$ was calculated. Prediction of growth reduction by $\left(\mathrm{Al}^{3+}\right.$ ) was only marginally better than by the measured concentrations of reactive $\mathrm{Al}$ and was improved in one case by including $\left(\mathrm{Ca}^{2+}\right)$ in multiple regression equations with $\mathrm{pH}$ and $\left(\mathrm{Al}^{3+}\right)$.

In topsoils, where organic ligands can be present in sufficient amounts to form complexes with a large proportion of the dissolved $\mathrm{Al}$, there still appears to be no satisfactory method for measuring the toxic fraction. Al which reacts within 15 seconds with 8-hydroxyquinoline (8-HQ) (James et al., 1983) is a good estimate of toxic $\mathrm{Al}$ in the presence of fluoride (Noble et al., 1988). However, this method appears to extract a variable proportion of $\mathrm{Al}$ which is complexed with organic ligands (James et al., 1983; Whitten and Ritchie, 1991). Given that organic acids have an ameliorating effect on $\mathrm{Al}$ toxicity (Hue et al., 1986; Tan and Binger, 1986), the inability of 8-HQ to distinguish toxic from non-toxic $\mathrm{Al}$ concentrations in soils (Adams and Hathcock, 1984) may be due to differences in the amount of organically complexed $\mathrm{Al}$ extracted or by differ- ences in the supply of ameliorating factors such as $\mathrm{Ca}$. Wright and Wright (1987) also used $\mathrm{Al}$ which reacts with $8-\mathrm{HQ}$ to estimate $\Sigma\left(\mathrm{Al}_{\text {mono }}\right)$ and $\left(\mathrm{Al}^{3+}\right)$ in topsoils and again found in one case that including a $\mathrm{Ca}$ term improved their model such that $\left(\mathrm{Ca}^{2+}\right) / \Sigma\left(\mathrm{Al}_{\text {mono }}\right)$ was a better predictor of growth reduction of subterranean clover than either $\Sigma\left(\mathrm{Al}_{\text {mono }}\right)$ or $\left(\mathrm{Al}^{3+}\right)$. Prediction of $\mathrm{Al}$ toxicity across a range of soils may therefore require inclusion of factors such as $\mathrm{Ca}$ or $\mathrm{P}$ which have been shown to alleviate $\mathrm{Al}$ toxicity (Blamey et al., 1983; Cameron et al., 1986) as well as the ability to discriminate between toxic and non-toxic forms of $\mathrm{Al}$.

The objectives of our work were: i) to compare the abilities of different types of soil extract and methods of estimating toxic Al to predict the growth and nodulation of subterranean clover in the presence of various amounts of $\mathrm{Al}$ in three topsoils from the Western Australian wheatbelt; ii) to identify which, if any, ameliorating factors could improve the predictive value of the soil test; and iii) to establish the relationship between $\mathrm{pH}$ or $\mathrm{Al}$ in the soil solution and the corresponding measurement in salt extracts.

\section{Materials and methods}

\section{Soil types}

Three sites in the Western Australian wheatbelt (Table 1) were sampled to a depth of approximately $10 \mathrm{~cm}$ after clearing the surface of plant debris. The soils were air-dried and sieved ( $\leq$ $2 \mathrm{~mm}$ ) immediately after collection. All sites had been cleared of native vegetation of at least 10 years. Soil 1 came from near Meckering (latitude $31^{\circ} 36^{\prime} \mathrm{S}$, longitude $116^{\circ} 65^{\prime} \mathrm{E}$ ) and was under

Table 1. Summary of soil properties

\begin{tabular}{|c|c|c|c|c|c|c|c|c|}
\hline \multirow[t]{2}{*}{$\overline{\text { Soil }}$} & \multirow{2}{*}{$\begin{array}{l}\text { Rainfall } \\
\text { mm yr }^{-1}\end{array}$} & \multirow{2}{*}{$\begin{array}{l}\text { Northcote } \\
\text { classification }\end{array}$} & \multirow[t]{2}{*}{$\mathrm{pH}^{\mathrm{a}}$} & \multirow[t]{2}{*}{$\mathrm{Al}^{\mathrm{b}}$} & \multirow{2}{*}{$\begin{array}{l}\text { Org. } C^{c} \\
(\%)\end{array}$} & \multicolumn{3}{|c|}{ Particle size $(\%)$} \\
\hline & & & & & & Sand & Silt & Clay \\
\hline 1 & 450 & Dy5.51 & 4.4 & 0.18 & 1.0 & 90 & 4 & 6 \\
\hline 2 & 450 & Dy5.51 & 4.4 & 0.20 & 1.0 & 89 & 4 & 7 \\
\hline 3 & 300 & $\mathrm{Gn} 2.21$ & 4.8 & 0.09 & 1.3 & 80 & 3 & 17 \\
\hline
\end{tabular}

a $1: 510 \mathrm{mM} \mathrm{CaCl}$.

${ }^{b}$ Exchangeable Al, 1:10 100 $\mathrm{m} M \mathrm{BaCl}_{2}, \mathrm{cmol}_{\mathrm{c}} \mathrm{kg}^{-1}$.

'Yeomans and Bremner, 1988. 
pasture. Soil 2 came from near Goomalling $\left(31^{\circ} 18^{\prime} \mathrm{S}, 116^{\circ} 50^{\prime} \mathrm{E}\right)$ and had been continuously cropped for the past 10 years. Soil 3 came from near Merredin $\left(31^{\circ} 29^{\prime} \mathrm{S}, 118^{\circ} 17^{\prime} \mathrm{E}\right)$ and was in the crop phase of a short crop:pasture rotation.

\section{Experimental design}

In a glasshouse pot trial Trifolium subterraneum L. cv. Mt Barker with and without rhizobial inoculation was grown in 3 soils with $8 \mathrm{pH}$ treatments and three replicates in randomized blocks. Uninoculated treatments received fertilizer N. Soil analyses were carried out on separate subsamples of the soils which had the same treatments as the plant growth subsamples except for $\mathrm{N}$ and trace elements.

\section{Nutrient addition and $\mathrm{pH}$ amendment}

The soil $\mathrm{pH}$ was adjusted with dilute $\mathrm{HCl}$ (range: $0.06-0.8$ cmole $\mathrm{H}^{+} \mathrm{kg}^{-1}$ ) or precipitated $\mathrm{CaCO}_{3}$ (equivalent to 1 and $2 \times 10^{3} \mathrm{~kg} \mathrm{ha}^{-1}$ assuming a bulk density of 1.6 and depth of incorporation $15 \mathrm{~cm}$ ). The unamended treatment received only de-ionised water. The target $\mathrm{pHs}$ in the soil solution were $3.8,4.0,4.2,4.4,4.6,4.8,5.5$ and 6.5. All treatments were incubated at field capacity at $40^{\circ} \mathrm{C}$ for 8 days which is equivalent to 32 days at $20^{\circ} \mathrm{C}$ according to the Arhennius equation (Castellan, 1970). Nutrient solutions supplying (mg kg ${ }^{-1}$ soil) $\mathrm{Na}_{2} \mathrm{MoO}_{4} 2 \mathrm{H}_{2} \mathrm{O}, 0.67$; $\mathrm{H}_{3} \mathrm{BO}_{3}, 0.83 ; \mathrm{CuSO}_{4} 5 \mathrm{H}_{2} \mathrm{O}, 5 ; \mathrm{ZnSO}_{4} 7 \mathrm{H}_{2} \mathrm{O}$, $10 ; \mathrm{MnSO}_{4} \mathrm{H}_{2} \mathrm{O}, 15 ; \mathrm{CoSO}_{4} 7 \mathrm{H}_{2} \mathrm{O}, 0.4 ; \mathrm{K}_{2} \mathrm{SO}_{4}$, 145; and $\mathrm{KH}_{2} \mathrm{PO}_{4}, 110$ (soils 1 and 2) and 176 (soil 3) were then applied as solutions to the surface of the soil which was then dried and mixed. These $P$ rates were selected from a preliminary $\mathbf{P}$ response experiment to produce $90 \%$ maximum growth in each soil in order to minimise the ameliorating effects that higher rates of $P$ could have on any $\mathrm{Al}$ toxicity in the acidified treatments. $\mathrm{N}$ was added to the $+\mathrm{N}$ treatments at the rate of $24 \mathrm{mg} \mathrm{N} \mathrm{kg}^{-1}$ as $\mathrm{NH}_{4} \mathrm{NO}_{3}$ immediately before sowing and every ten days thereafter. All reagents were analytical grade.

\section{Glasshouse experiment}

Germinated seed with radicles of approximately
$2 \mathrm{~mm}$ were sown into 25 evenly spaced $10-\mathrm{mm}$ depressions in soil at field capacity in lined 3-kg pots. The plants were thinned to 20 plants per pot on day 7 . Inoculated treatments received $1 \mathrm{~mL}$ of a suspension containing approximately $10^{7}$ colony-forming units of Rhizobium leguminosarum bv trifolii TA1 which was pipetted into the depressions before seeding. The replicates were arranged in randomised blocks in separate root-cooling tanks in which the temperature was maintained at approximately $20^{\circ} \mathrm{C}$. Air temperature varied between approximately $15^{\circ}-30^{\circ} \mathrm{C}$. Pots were watered daily with deionised water, initially to $80 \%$ field capacity and later to field capacity as demand increased. Damping-off was controlled with 2 treatments on days 13 and 20 with a systemic fungicide (Fongarid ${ }^{\circledR}$, Ciba-Geigy, Basle, Switzerland). Harvest commenced on day 35 with 1 replicate harvested on each of 3 successive days.

\section{Soil extracts and analyses}

Three types of soil extract were obtained. Soil solutions were extracted by centrifugation (Gillman, 1976) after incubating the soils at field capacity for $16 \mathrm{hr}$ at $20^{\circ} \mathrm{C}$. Salt extracts were obtained by shaking the soil end-over-end for 16 hours at $20^{\circ} \mathrm{C}$ at a soil:solution ratio of $1: 5(\mathrm{w} / \mathrm{v})$ with $30 \mathrm{~m} M \mathrm{KCl}, 10 \mathrm{~m} M \mathrm{CaCl}_{2}$, and $5 \mathrm{~m} M$ $\mathrm{LaCl}_{3}$ (ionic strength 0.03 ) or at a soil: solution ratio of $1: 10$ (w/v) in $100 \mathrm{~m} M \mathrm{BaCl}_{2}$ to determine exchangeable ions. All extracts were filtered through $0.45-\mu \mathrm{m}$ membrane filters (Millipore type HA).

Reactive $\mathrm{Al}$ was estimated by the $8-\mathrm{HQ}$ method (James et al, 1983, hence referred to as Al-HQ) in the soil solutions and 1:5 extracts and by Chelex-100 ${ }^{\circledR}$, a cation exchange resin (Al-res; Whitten and Ritchie, 1991) in the soil solutions only. Total Al (Al-tot) was measured in the $\mathrm{LaCl}_{3}$ extracts with 8-HQ using the same reagents as James et al. (1983) for total Al, and in all other extracts with pyrocatechol violet based on the method of Dougan and Wilson (1974). PyeUnicam SP8-150 or SP6-550 UV-Vis spectrophotometers were used for the colorimetric determinations. Al standards were made up at $\mathrm{pH} 3$ from a stock solution of AR-grade Al wire dissolved in $\mathrm{HCl}$ using mercury as a catalyst. 
$\mathrm{Ca}, \mathrm{Mg}, \mathrm{K}$ and $\mathrm{Na}$ in the soil solutions and $\mathrm{BaCl}_{2}$ extracts were determined by flame atomic absorption spectrophotometry (FAAS) on a Perkin Elmer model 403. Standards and sample dilutions were made with a solution of $1000 \mathrm{mg} \mathrm{L}^{-1} \mathrm{Cs}$ as $\mathrm{CsCl}$ in $100 \mathrm{~m} M \mathrm{HCl}$. A nitrous oxide flame was used for $\mathrm{Ca}$ and $\mathrm{Mg}$ determinations to remove potential interference from $\mathrm{P}, \mathrm{Al}$ and Si. Phosphorus was measured by the molybdenum-blue method (John, 1970) in the soil solutions and $\mathrm{CaCl}_{2}$ extracts. Measurements of $\mathrm{pH}$ in the extracts and soil solutions were made on the day of extraction with a combination electrode and an Orion Research EA 940 meter. Electrical conductivity in the soil solution was measured with an Activon PT-18 digital conductivity meter with automatic temperature correction and calibrated with standard solutions of $\mathrm{KCl}$. The relative concentration of dissolved organic matter in the soil solution was estimated by measuring the spectrophotometric absorbance at $240 \mathrm{~nm}$ with a 1-mm quartz cuvette.

The ionic strength of the soil solution was estimated from the electrical conductivity of the soil solution using the formula of Gilman and Bell (1978).

The phosphate retention index (PRI) of each soil was determined in triplicate by shaking $1 \mathrm{~g}$ air-dry soil for $16 \mathrm{~h}$ at $20^{\circ} \mathrm{C}$ in $10 \mathrm{~mL} 10 \mathrm{mM} \mathrm{KCl}$ containing $10 \mathrm{mg} \mathrm{L}^{-1} \mathrm{P}$ as $\mathrm{KH}_{2} \mathrm{PO}_{4}$. The solution was then centrifuged, filtered through a $0.45-\mu \mathrm{m}$ filter (Millipore type $\mathrm{HV}$ ), and the $\mathrm{P}$ concentration determined by the molybdenum-blue method (John, 1970). The PRI was then calculated as the amount of $P$ adsorbed by the soil divided by the final concentration of $P$.

\section{Plant analyses and growth measurements}

Shoots were dried and ground in a hammer mill to pass through a 1-mm screen. After further drying at $70^{\circ} \mathrm{C}$ overnight, subsamples from each replicate were digested in a 4:1 nitric:perchloric acid mix (Johnson and Ulrich, 1959) and analysed for $\mathrm{Ca}, \mathrm{Mg}$ by FAAS and P by the molybdovandadate method (Hanson, 1950). Nodules were counted on the uppermost $20 \mathrm{~mm}$ of the taproot and on the first $10 \mathrm{~mm}$ of laterals originating within this zone.

\section{Data analysis}

Growth data were related to soil parameters by fitting exponential models (Genstat 5; Rothamsted Statistics Department, 1987) and by stepwise multiple linear regression using forward selection (Statview 1.03; Abacus Concepts, Inc., 1988).

\section{Results}

\section{Effects of acidity}

In all three soils, the concentrations of Al-tot and reactive $\mathrm{Al}$ in the soil solution and 1:5 extracts (Fig. 1) increased as $\mathrm{pH}$ decreased. Plant growth and early nodulation decreased with increasing $\mathrm{Al}$ (Fig. 2; data for Al-HQ only presented).

\section{Concentrations and forms of $A l$ in soils}

At a constant $\mathrm{pH}$, the concentration of total $\mathrm{Al}$ in the different extracts tended to be highest in the soil solution and decreased in the order $\mathrm{LaCl}_{3}>\mathrm{CaCl}_{2}>\mathrm{KCl}$. In any one extract, the concentration of $\mathrm{Al}$ tended to be lower in soil 3 than soils 1 and 2. The total amount of $\mathrm{Al}$ extracted per unit weight of soil by each type of extract decreased in the order $\mathrm{BaCl}_{2}>\mathrm{LaCl}_{3}>$ $\mathrm{CaCl}_{2}>\mathrm{KCl}>$ soil solution.

The two measures of reactive $\mathrm{Al}$ extracted different proportions of Al-tot from the soil solution. The cation exchange resin extracted most of Al-tot from the soil solutions of all soils. This contrasts with previous work in which the proportion of $\mathrm{Al}$ which exchanged with the resin was controlled by the ratio of $\mathrm{Al}$ to organic complexing groups (Whitten and Ritchie, 1991). The concentration of $\mathrm{Al}-\mathrm{HQ}$ in the soil solution and the $\mathrm{KCl}$ and $\mathrm{CaCl}_{2}$ extracts was $<50 \%$ of Al-tot, whereas it was nearly $90 \%$ of $\mathrm{Al}$-tot in $\mathrm{LaCl}_{3}$ extracts. The concentration of $\mathrm{Al}-\mathrm{HQ}$ in the soil solution and 1:5 extracts was linearly related to Al-tot in the same extract, but the proportion of $\mathrm{Al}-\mathrm{HQ}$ was greater $(p<0.05)$ in soil 3 than in soils 1 and 2 , except in $\mathrm{LaCl}_{3}$ in which it was approximately the same in all 3 soils (Fig. 3). 


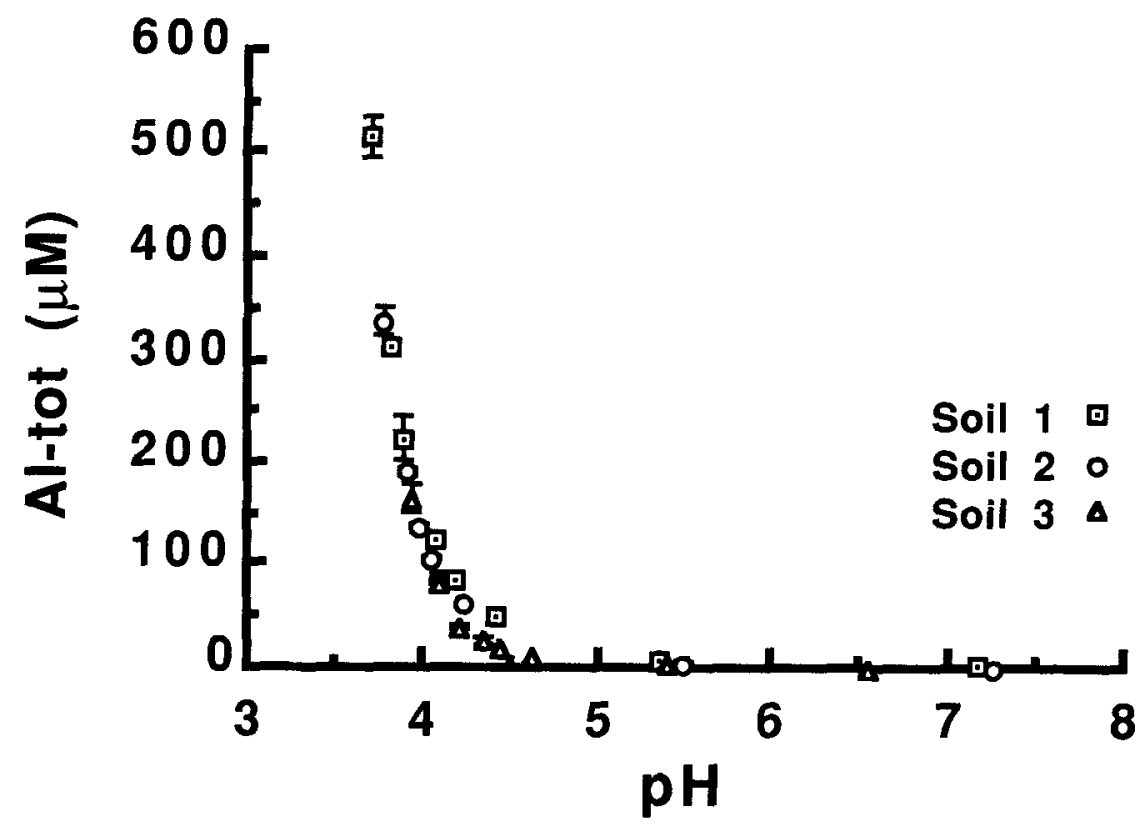

Fig. 1. The concentration of Al-tot $(\mu M)$ in the soil solution plotted against the pH. Error bars are standard errors of means.

Correlation between the $\mathrm{pH}$ in the soil solution and $1: 5$ extracts

The $\mathrm{pH}$ of the 1:5 extracts from all soils was linearly correlated with the $\mathrm{pH}$ of the soil solution $\left(\mathrm{r}^{2} \geq 0.98\right.$ in all cases). The $\mathrm{pH}$ of the $\mathrm{KCl}$ extract was not significantly different from that measured in $\mathrm{CaCl}_{2}$. The $\mathrm{pH}$ in both $\mathrm{KCl}$ and $\mathrm{CaCl}_{2}$ was higher than in the soil solution, except at the higher rate of lime. In contrast, the $\mathrm{pH}$ in $\mathrm{LaCl}_{3}$ was similar to that in the soil solution in the most acidic treatment, but was much lower in the limed treatments and was significantly less $(p<0.05)$ than in $\mathrm{KCl}$ and $\mathrm{CaCl}_{2}$.

Relationship between reactive $A l$ in the soil solution and 1:5 extracts

The relationships between the concentration of reactive $\mathrm{Al}$ in the soil solution and the corresponding measurement in 1:5 extracts were nonlinear and showed increasing curvature as the valence of the extracting cation increased from +1 for $\mathrm{KCl}$ to +3 for $\mathrm{LaCl}_{3}$. The exponential regression equations $\left(\mathrm{y}=\mathrm{A}+\mathrm{B} \mathrm{e}^{-\mathrm{cx}}\right.$, where $\mathrm{A}$, $B$ and $c$ represent the intercept, asymptote and curvature, respectively) for $\mathrm{Al}-\mathrm{HQ}$ in the 1:5 extracts (y) vs $\mathrm{Al}-\mathrm{HQ}$ in the soil solution (x) were $\quad \mathrm{y}=31.36-29.97 \mathrm{e}^{-0.0025 \mathrm{x}}, \quad \mathrm{y}=35.42-$ $34.69 \mathrm{e}^{-0.0112 \mathrm{x}}$ and $\mathrm{y}=144.60-146.29 \mathrm{e}^{-0.0501 x}$, for $\mathrm{KCl}, \mathrm{CaCl}_{2}$ and $\mathrm{LaCl}_{3}$, respectively. The differences in curvature were significant ( $p<$ 0.05 ) in all cases, and the intercept and asymptote for $\mathrm{LaCl}_{3}$ were also significantly different from the corresponding values for $\mathrm{KCl}$ and $\mathrm{CaCl}_{2}$.

\section{$\mathrm{P}, \mathrm{Ca}, \mathrm{Mg}, \mathrm{K}$ and $\mathrm{Na}$ in soil solution and 1:5} extracts

The concentration of $\mathrm{P}$ in $\mathrm{CaCl}_{2}$ increased slightly with increasing acidity in soils 1 and 2 , but there was no clear effect of $\mathrm{pH}$ on the concentration of $\mathbf{P}$ in the soil solution in any of the soils. The concentration of $\mathrm{P}$ in the soil solution was highest in soil 2 (average $42.1 \mu M$ ), followed by soil $1(15.4 \mu M)$ and lowest in soil 3 $(6.1 \mu M)$. The relationship between the concentration of $\mathrm{P}$ in the $\mathrm{CaCl}_{2}$ extract and that in the soil solution was linear over all soils $(y=0.06+$ $0.27 \mathrm{x}, \mathrm{r}^{2}=0.96$ ). The phosphate retention index (PRI) of each soil increased as the $\mathrm{pH}$ decreased and was higher in soil $3(3.8-5.6)$ than in soil 1 $(1.2-2.5)$ and soil $2(1.1-2.3)$. The concentrations of $\mathrm{P}$ in the soil solution and $\mathrm{CaCl}_{2}$ extract were not linearly related to the PRI. 

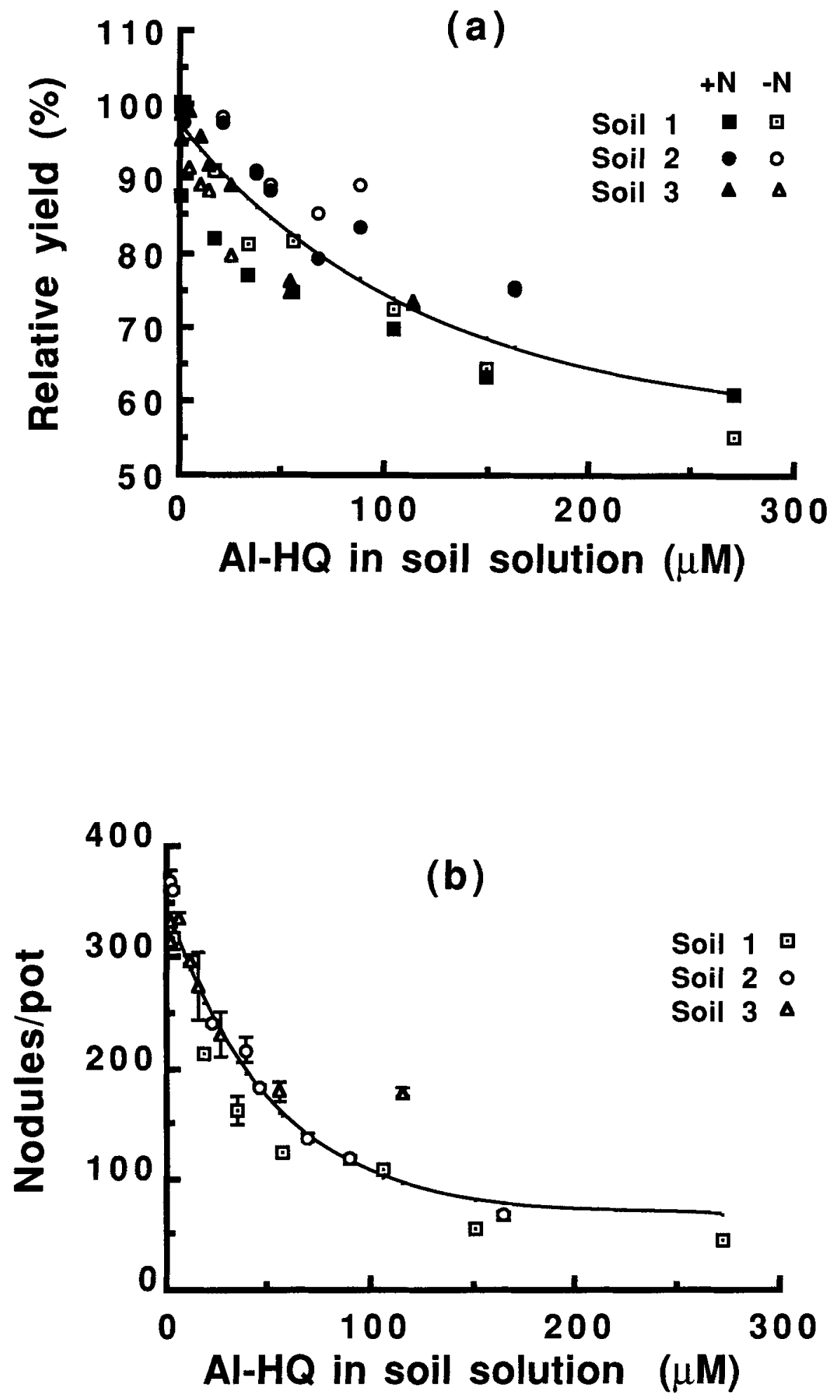

Fig. 2. Relative shoot dry weight expressed as a percentage of the maximum within each soil and $\mathrm{N}$ source (a) and number of early nodules (b) plotted against the concentration of $\mathrm{Al}-\mathrm{HQ}(\mu M)$ in the soil solution. 

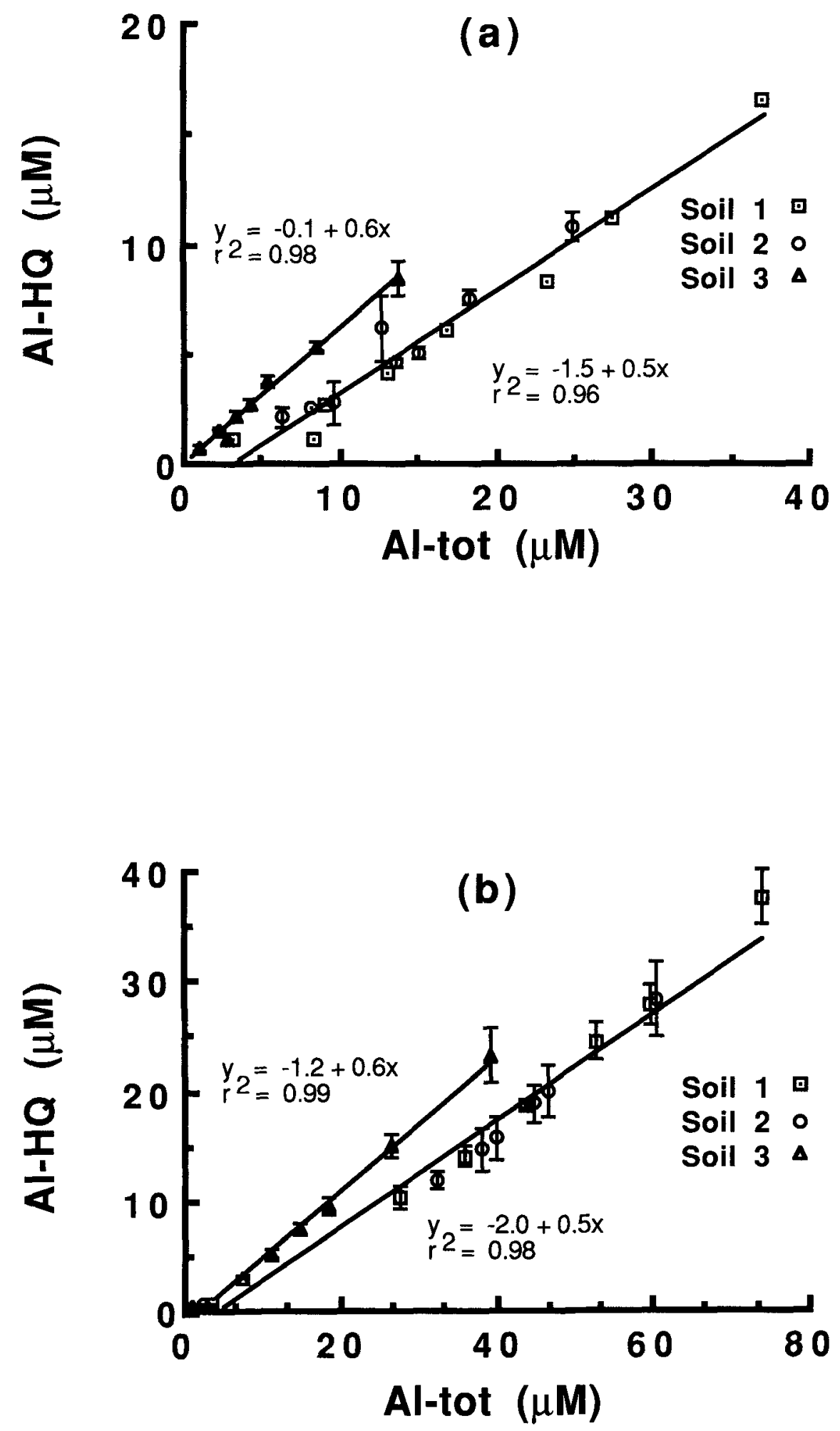

Fig. 3. The concentration of Al-HQ $(\mu M)$ plotted against the concentration of Al-tot $(\mu M)$ in $1: 530 \mathrm{~m} M \mathrm{KCl}$ extracts (a), $1: 5$ $10 \mathrm{mM} \mathrm{CaCl}$ extracts (b), $1: 55 \mathrm{mM} \mathrm{LaCl}$ extracts (c) and soil solution (d). Error bars are standard errors of means. 

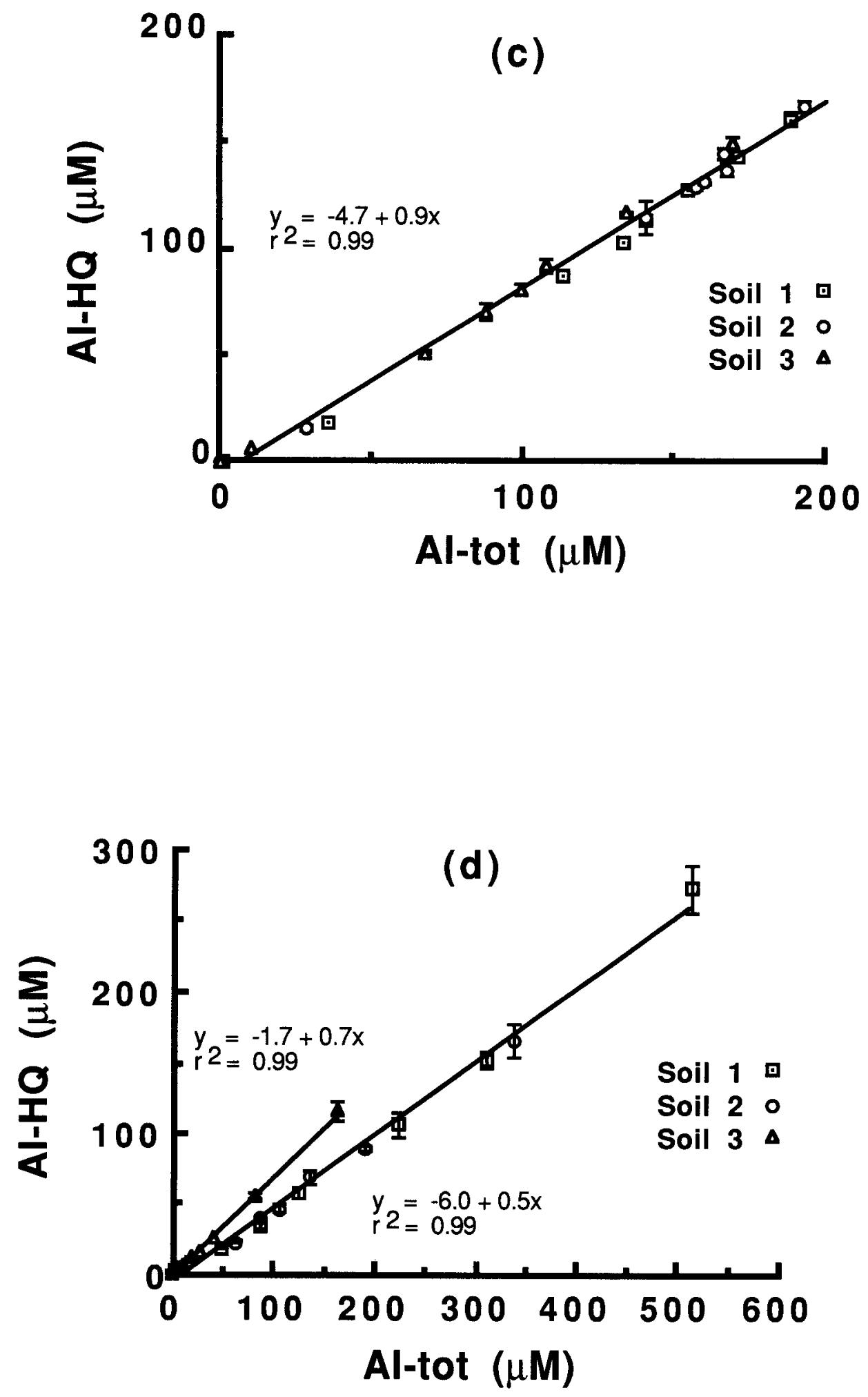

Fig. 3. (continued). 
Adding acid increased the concentrations of Ca $(2-20 \mathrm{~m} M), \mathrm{Mg}(2-11 \mathrm{~m} M), \mathrm{K}(5-12 \mathrm{~m} M)$ and $\mathrm{Na}(4-10 \mathrm{mM})$ in the soil solution in all soils, whereas adding lime only increased $\mathrm{Ca}$ $(2-5 \mathrm{~m} M)$. The ionic strengths in the soil solutions increased from approximately 0.03 to 0.09 .

\section{UV absorbance of soil solution}

The UV absorbance at $240 \mathrm{~nm}$ decreased in all soils as the $\mathrm{pH}$ decreased and the concentration of $\mathrm{Al}$ increased. The values were slightly lower in soil 3 than in soils 1 and 2, except in the limed treatments.

\section{Growth and nutrient uptake by subterranean clover}

Plant growth was at a maximum within each soil type at the higher rate of lime addition in the $\mathrm{N}$-fixing treatments in all soils, and at the lower rate of lime when fertilised with $\mathrm{NH}_{4} \mathrm{NO}_{3}$. The order of decreasing response to acidity for plant growth was soil $1>$ soil $3>$ soil 2 and for nodulation soil $2>$ soil $1>$ soil 3 .

As acidity increased, the concentration of $\mathrm{Ca}$ in the whole tops in soils 1 and 3 and of $\mathrm{Mg}$ in all soils increased. The $P$ concentration in plants grown in soils 1 and 3 decreased as Al-HQ increased (Fig. 4).

Root dry weights decreased with increasing acidity in all treatments, whereas root length decreased only in the $\mathrm{N}$-fixing treatments in soils 1 and 2 (data not shown). Over all treatments, there was a linear relationship between root weight and root length $(\mathrm{y}=0.0987+0.0034 \mathrm{x}$, $r^{2}=0.61$, slope significant at $p<0.05$ ).

\section{Correlation of yield and nodulation with different measures of $\mathrm{pH}$ and $\mathrm{Al}$}

The number of early nodules decreased as acidity increased, and increased as plant growth increased. The relationship between nodulation or relative yield and measures of $\mathrm{pH}$ and $\mathrm{Al}$ over the entire range of $\mathrm{pH}$ treatments could be described by an exponential equation of the form $\mathrm{Y}=\mathrm{A}+\mathrm{Be}^{-\mathrm{cx}}$. Using this model for all soils, relative yield was correlated better with $\mathrm{Al}-\mathrm{HQ}$ $\left(\mathrm{r}^{2}=0.76-0.78\right)$ than with Al-tot and Al-res $\left(r^{2}=0.68-0.74\right)$ or $\mathrm{pH}\left(\mathrm{r}^{2}=0.70-0.77\right)$ in the soil solution and the $\mathrm{KCl}$ and $\mathrm{CaCl}_{2}$ extracts. Both exchangeable $\mathrm{H}$ and $\mathrm{Al}$ were correlated with relative yield $\left(\mathrm{r}^{2}=0.71\right.$ and 0.80 , respec-

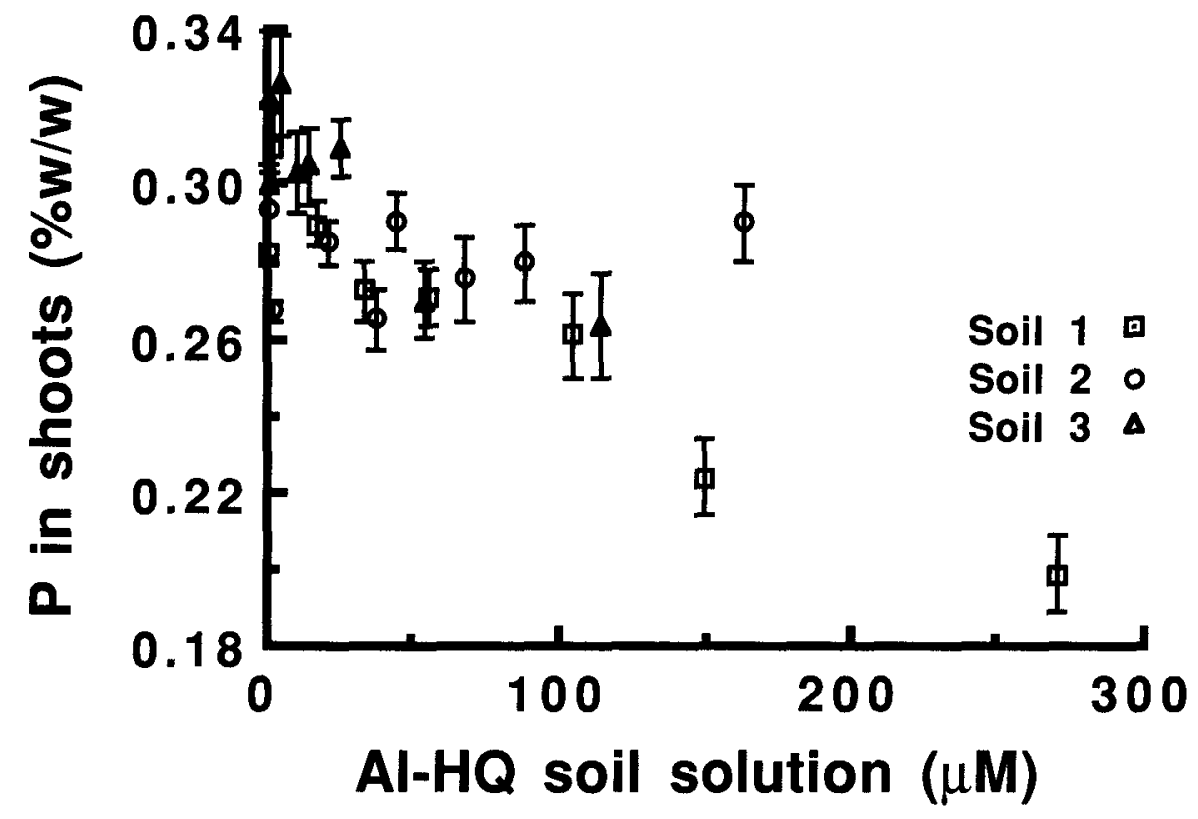

Fig. 4. The concentration of $\mathrm{P}(\% \mathrm{w} / \mathrm{w})$ in the whole tops of subterranean clover plotted against $\mathrm{Al}-\mathrm{HQ}(\mu M)$ in the soil solution. Error bars are standard errors of means. 
tively). With the $\mathrm{LaCl}_{3}$ extracts there was a poorer correlation between relative yield and $\mathrm{pH}$ $\left(\mathrm{r}^{2}=0.61\right)$ or both measures of $\mathrm{Al}\left(\mathrm{r}^{2}=0.58\right.$ 0.59 ). Early nodulation was well correlated with $\mathrm{pH}\left(\mathrm{r}^{2}=0.87-0.92\right)$ and all measures of $\mathrm{Al}$ $\left(r^{2}=0.81-0.94\right)$. In most cases, correlation coefficients were higher for individual soils and $\mathrm{N}$ treatments than when the data from all soils were combined (data not presented).

The response curves for plant growth plotted against $\mathrm{pH}$ in all extracts, exchangeable $\mathrm{H}$ and $\mathrm{Al}$ and $\mathrm{Al}$ in $\mathrm{LaCl}_{3}$ extracts were characterised by a plateau with a wide separation between the data points for the limed treatments and those of the unamended an acidified treatments. With the limed data excluded, Al-HQ explained more of the variation in relative yield (Table $2 ; \mathrm{r}^{2}=0.68-$ 0.70), than Al-tot and exchangeable $\mathrm{Al}$ $\left(\mathrm{r}^{2}=0.54-0.64\right)$ or exchangeable $\mathrm{H}$ and $\mathrm{pH}\left(\mathrm{r}^{2}=\right.$ $0.49-0.57)$ in the soil solution and the $\mathrm{CaCl}_{2}$ and

Table 2. Variation (significant at $p<0.05$ ) in relative yield of subterranean clover in acidified and unlimed treatments as explained by $\mathrm{pH}$, Al-tot, Al-HQ, Al-res, exchangeable Al and $\mathrm{H}$ with the concentration of $\mathrm{P}$ and $\mathrm{Ca}$ in the soil solution and quadratic term for the $\mathrm{Al}$ and $\mathrm{pH}$ measurements, using stepwise multiple regression

\begin{tabular}{|c|c|c|c|c|c|}
\hline \multirow[t]{3}{*}{ Model } & \multicolumn{5}{|l|}{ Extract } \\
\hline & \multirow{2}{*}{$\begin{array}{l}\text { Soil } \\
\text { solution }\end{array}$} & \multicolumn{3}{|l|}{$1: 5$} & \multirow{2}{*}{$\begin{array}{l}1: 10 \\
\mathrm{BaCl}_{2} \\
0.1 \mathrm{M}\end{array}$} \\
\hline & & $\begin{array}{l}\mathrm{KCl} \\
0.03 M\end{array}$ & $\begin{array}{l}\mathrm{CaCl}_{2} \\
0.01 M\end{array}$ & $\begin{array}{l}\mathrm{LaCl}_{3} \\
0.005 M\end{array}$ & \\
\hline $\mathrm{pH}$ & 0.55 & 0.57 & 0.49 & 0.37 & 0.58 \\
\hline +PSS & 0.84 & 0.87 & 0.80 & 0.84 & 0.79 \\
\hline$+\mathrm{CaSS}$ & 0.88 & NS & 0.82 & 0.86 & NS \\
\hline +quadratic & NS & 0.88 & NS & NS & NS \\
\hline Al-tot & 0.64 & 0.63 & 0.54 & 0.35 & 0.64 \\
\hline +PSS & 0.78 & 0.84 & 0.88 & 0.84 & 0.85 \\
\hline + Ca SS & NS & 0.87 & 0.90 & 0.86 & NS \\
\hline +quadratic & 0.85 & 0.89 & NS & NS & NS \\
\hline Al-HQ & 0.68 & 0.70 & 0.70 & 0.37 & \\
\hline +PSS & 0.77 & 0.80 & 0.88 & 0.79 & \\
\hline$+\mathrm{CaSS}$ & NS & NS & NS & 0.85 & \\
\hline +quadratic & 0.83 & 0.83 & NS & NS & \\
\hline Al-res & 0.64 & & & & \\
\hline +PSS & 0.78 & & & & \\
\hline +CaSS & NS & & & & \\
\hline +quadratic & 0.84 & & & & \\
\hline
\end{tabular}

NS = improvement in $r^{2}$ not significant.
$\mathrm{KCl}$ extracts. Early nodulation (Table 3) was correlated slightly better with $\mathrm{pH}\left(\mathrm{r}^{2}=0.81-\right.$ $0.91)$ than with Al-tot $\left(r^{2}=0.74-0.90\right)$ and AlHQ $\left(r^{2}=0.67-0.87\right)$.

Stepwise multiple linear regression (using forward selection) between relative yield over all soils from the acidified and unlimed treatments and each measure of $\mathrm{pH}$ or $\mathrm{Al}$ combined with the concentration of $\mathbf{P}$ in the soil solution explained more variation than the corresponding soil test parameter alone (Table 2 ). The coefficients for $\mathrm{P}$ were all highly significant $(p<0.01)$. An additional small increase in percentage variation explained was gained in some cases by including the concentration of $\mathrm{Ca}$ in the soil solution as a third explanatory variable. However, the improvement gained by including a term for $\mathrm{P}$ or $\mathrm{P}$ and $\mathrm{Ca}$ in most cases fell short of the $r^{2}$ values for relative yield vs the corresponding single soil test parameter for individual soils.

Table 3. Variation (significant at $p<0.05$ ) in number of early nodules in acidified and unlimed treatments as explained by $\mathrm{pH}, \mathrm{Al}$-tot, $\mathrm{Al}-\mathrm{HQ}, \mathrm{Al}-\mathrm{res}$, exchangeable $\mathrm{Al}$ and $\mathrm{H}$ with the concentration of $\mathbf{P}$ and $\mathrm{Ca}$ in the soil solution and quadratic term for the $\mathrm{Al}$ and $\mathrm{pH}$ measurements, using stepwise multiple regression

\begin{tabular}{|c|c|c|c|c|c|}
\hline \multirow[t]{3}{*}{ Model } & \multicolumn{5}{|l|}{ Extract } \\
\hline & \multirow{2}{*}{$\begin{array}{l}\text { Soil } \\
\text { solution }\end{array}$} & \multicolumn{3}{|l|}{$1: 5$} & \multirow{2}{*}{$\begin{array}{l}\frac{1: 10}{\mathrm{BaCl}_{2}} \\
0.1 \mathrm{M}\end{array}$} \\
\hline & & $\begin{array}{l}\mathrm{KCl} \\
0.03 M\end{array}$ & $\begin{array}{l}\mathrm{CaCl}_{2} \\
0.01 M\end{array}$ & $\begin{array}{l}\mathrm{LaCl}_{3} \\
0.005 M\end{array}$ & \\
\hline $\mathrm{pH}$ & 0.86 & 0.91 & 0.81 & 0.79 & 0.78 \\
\hline +P SS & 0.94 & NS & NS & 0.84 & NS \\
\hline$+\mathrm{Ca} \mathrm{SS}$ & 0.89 & NS & NS & 0.89 & NS \\
\hline + quadratic & NS & NS & NS & NS & NS \\
\hline Al-tot & 0.74 & 0.86 & 0.90 & 0.76 & 0.86 \\
\hline$+\mathrm{PSS}$ & NS & NS & NS & 0.81 & NS \\
\hline$+\mathrm{Ca} S \mathrm{~S}$ & NS & NS & NS & 0.85 & NS \\
\hline + quadratic & 0.89 & 0.92 & NS & NS & NS \\
\hline Al-HQ & 0.67 & 0.73 & 0.87 & 0.73 & \\
\hline+ P SS & NS & NS & NS & NS & \\
\hline + Ca SS & NS & NS & NS & NS & \\
\hline +quadratic & 0.81 & 0.81 & 0.91 & NS & \\
\hline Al-res & 0.73 & & & & \\
\hline+ P SS & NS & & & & \\
\hline + Ca SS & NS & & & & \\
\hline + quadratic & 0.88 & & & & \\
\hline
\end{tabular}

NS = improvement in $r^{2}$ not significant. 
The inclusion of a quadratic term for the major explanatory variable in the above multiple regressions was significant only for the $\mathrm{Al}$ measurements in the soil solution and all measurements in the $\mathrm{KCl}$ extracts, and accounted for between $2-7 \%$ of the variation (Table 2).

With similar multiple regression analysis for early nodulation, $\mathrm{Ca}$ and $\mathbf{P}$ were significant $(p<$ 0.05 ) explanatory variables only with $\mathrm{pH}$ in the soil solution and with $\mathrm{pH}$ and $\mathrm{Al}$-tot in the $\mathrm{LaCl}_{3}$ extracts, but only increased the percentage variation explained by $5-8 \%$. The quadratic term of the major explanatory variable was significant $(p<0.05)$ for all Al measurements in the soil solution and $\mathrm{KCl}$ extracts and for $\mathrm{Al}-\mathrm{HQ}$ in the $\mathrm{CaCl}_{2}$ extracts (Table 3 ).

The UV absorbance estimate of dissolved organic matter was not significant in any of the multiple regression analyses.

\section{Discussion}

Al measured by the $15 \mathrm{sec}$. 8-HQ method explained more of the variation in relative yield in the acidified and unlimed treatments than either the total concentration of $\mathrm{Al}$ or $\mathrm{pH}$ in the corresponding extract. Including the concentration of $\mathrm{P}$ in the soil solution as a secondary explanatory variable increased the percentage of variation in relative yield explained by each soil test parameter. Little or no improvement was gained by including $\mathrm{Ca}$ in the multiple regression analysis. The concentration of $\mathrm{Al}-\mathrm{HQ}$ in 1:5 extracts in $\mathrm{KCl}$ or $\mathrm{CaCl}_{2}$ at the same ionic strength as the soil solution are equally good predictors of $\mathrm{Al}$ toxicity as that in the soil solution. At a constant ionic strength, increasing the charge on the extracting cation in 1:5 extracts lowered the $\mathrm{pH}$ of the extract and increased both the amount of $\mathrm{Al}$ extracted from the soil and the proportion of uncomplexed $\mathrm{Al}$.

\section{Plant growth}

In the soils studied, not all soluble $\mathrm{Al}$ was phytotoxic and phosphorus was a more important ameliorating factor than calcium. The main chemical differences between the three soils were the higher proportion of $\mathrm{Al}-\mathrm{HQ}$ in soil
3 compared with soils 1 and 2 , and the range of concentrations of $\mathrm{P}$ in the soil solution. The latter reflects the differences between their $P$ histories and P-fixing capacities, and appears to have resulted in a range of $\mathrm{P}$ :toxic $\mathrm{Al}$ ratios which span a threshold value below which there is no ameliorative effect. Not only was the absolute yield of dry matter higher in soil 2 than in soils 1 and 3 , but the percentage decrease in yield at any concentration of $\mathrm{Al}$ or $\mathrm{pH}$ tended to be less in soil 2 than in soils 1 and 3 . The argument for soil 2 having sufficient $P$ to partly counteract $\mathrm{Al}$ toxicity is also supported by the decrease in $\mathbf{P}$ content of the whole tops with increasing acidity in soils 1 and 3, but not in soil 2 . This decrease was proportionately greater than the corresponding decrease in $\mathrm{P}$ concentration in the soil solutions. In contrast, Kim et al. (1985b) observed an increase in $P$ content of the tops of subterranean clover when $\mathrm{pH}$ decreased from 4.5 to 4.0 in the absence of $\mathrm{Al}$. A possible explanation for this difference is that uptake of $\mathrm{P}$ is inhibited by $\mathrm{Al}$ at low concentrations of $P$, but once the $P$ concentration is above a certain threshold, Al toxicity is mitigated without a decrease in $\mathrm{P}$ uptake.

Munns (1965) found that in solution culture $\mathrm{Al}$ decreased the concentration of $P$ in shoots of subterranean clover as a result of decreased root length and that increasing the concentration of $\mathrm{Ca}$ prevented this. The relatively small percentage of variation explained by the inclusion of $\mathrm{Ca}$ in multiple regression of relative yield against $\mathrm{Al}$ or $\mathrm{pH}$ with $\mathrm{P}$ and $\mathrm{Ca}$ in the soil solution may be due to the concentration of $\mathrm{Ca}$ being more than adequate in each soil.

\section{Nodulation}

Neither $\mathbf{P}$ nor $\mathrm{Ca}$ improved the ability of the $\mathrm{Al}$ soil tests to predict nodulation in the presence of $\mathrm{Al}$. This may reflect a lower requirement by the rhizobia for $\mathrm{Ca}$ and/or $\mathrm{P}$ compared with growth of the host plants. Nodulation was affected less by $\mathrm{Al}$ and/or $\mathrm{H}$ toxicity in this experiment than was the case in the solution-culture studies of Kim et al. (1985a). They found that nodulation of subterranean clover was significantly decreased at $6.4 \mu M$ monomeric $\mathrm{Al}$ and $\mathrm{pH} 4.5$ compared with the zero $\mathrm{Al}$ treatments. In this 
work, nodulation was at least $75 \%$ of maximum at $\mathrm{pH}$ of $4.2-4.4$ and $\mathrm{Al}-\mathrm{HQ}$ of $11-22 \mu M$. The concentration of $\mathrm{P}(7-40 \mu M)$ and $\mathrm{Ca}$ (2$10 \mu M$ ) in our soil solutions were higher than in the solution cultures of Kim et al. (1985a) and may have been sufficiently high to decrease the toxicity of $\mathrm{Al}$ to the rhizobia or nodulation process. Alternatively, the more concentrated inoculant in this work $\left(10^{7} \mathrm{~mL}^{-1}\right)$ compared with that in the solution studies $\left(10^{4} \mathrm{~mL}^{-1}\right)$ may account for the apparent greater tolerance of $\mathrm{Al}$ and low $\mathrm{pH}$ in this experiment. Robson (1970) found that the critical $\mathrm{pH}$ for nodulation of medic grown in acidic soil decreased as the inoculant density increased.

\section{Improving soil tests for Al toxicity}

Combining estimates of phytotoxic $\mathrm{Al}$ and ameliorating nutrients in soil tests raises the problem of sampling strategy. In the pot experiment described here, the soil had been mixed thoroughly, whereas in the field some degree of vertical stratification would be expected. Soil $\mathrm{pH}$ profiles under subterranean clover for at least 5 years can develop a sharp decline in $\mathrm{pH}$ below the top $2 \mathrm{~cm}$ (Williams, 1980; Conyers and Scott, 1989; McLaughlin et al., 1990). This may also occur in shorter rotations where cultivation disturbs but does not mix or invert the top $10 \mathrm{~cm}$. McLaughlin et al. (1990) found that in soils which had been under subterranean clover pasture for up to 8 years, the concentration of $P$ extracted in $\mathrm{HF}_{4} \mathrm{~F} / \mathrm{HCl}$ was highest in the top $2 \mathrm{~cm}$ and decreased with depth, and concentration of $\mathrm{Al}$ extracted in 1:5 $0.01 \mathrm{M} \mathrm{CaCl}_{2}$ was low in the top $2 \mathrm{~cm}$ and high from 2 to $10 \mathrm{~cm}$. They suggest that prediction of lime and fertiliser requirements on such soils may be improved by taking separate soil samples from $0-2$ and 2$10 \mathrm{~cm}$ depths. The Al:P molar ratio in the soil solution could increase with depth within the $2-10 \mathrm{~cm}$ layer, and a given concentration of $\mathrm{Al}$ in the soil solution may be more toxic at $10 \mathrm{~cm}$ than at $2 \mathrm{~cm}$. McLaughlin and James (1989) have shown that $P$ in the surface layers does not have an ameliorating effect on $\mathrm{Al}$ toxicity at depth. Soil tests for Al toxicity may therefore improve, if measurements of $\mathrm{Al}$ and ameliorating nutrients are made on samples taken from $2-5 \mathrm{~cm}$ and $5-10 \mathrm{~cm}$.
Although $\mathrm{pH}$ appeared to be an adequate predictor for the effects of acidity on nodulation in our experiment, this may not be the case in the field. Preliminary results from analyses of soils from lime trials in the field over a range of soils indicate that the relationship between the concentration of $\mathrm{Al}$ and $\mathrm{pH}$ in the soil solution varies more than was the case in the experiment described here. The 15 -sec $8-\mathrm{HQ}$ method still appears to be the best colorimetric method available for estimating phytotoxic $\mathrm{Al}$ in soils with relatively low organic content. Recent studies by Kerven et al. (1989a) confirm that in the presence of fulvate, 8-HQ reacts with less organically complexed $\mathrm{Al}$ than other commonly used shortterm colorimetric methods. At $\mathrm{pH} 4.5$ and $50 \mu M \mathrm{Al}$ present as $100 \% \mathrm{Al}$-fulvate, $46 \%$ of the complexed $\mathrm{Al}$ reacted with 8 -HQ in $15 \mathrm{sec}$, whereas $82 \%$ reacted with aluminon in $30 \mathrm{~min}$. In similar Al-fulvate solutions (Al $100 \mu M, \mathrm{pH}$ 4.5) approximately $58 \%$ and $66 \%$ of the organically complexed $\mathrm{Al}$ reacted with pyrocatechol violet in 30 and $60 \mathrm{sec}$, respectively (Kerven et al., 1989b).

\section{Comparison of extracts}

At a constant ionic strength, increasing the charge on the extracting cation decreased the correlation between plant growth parameters and different measures of $\mathrm{Al}$ by decreasing the $\mathrm{pH}$, increasing Al-tot and increasing the proportion of Al-HQ. This suggests that it is more important to measure the soluble toxic forms of Al than to know the soil's ability to replenish the soluble toxic forms. The more linear relationship between $\mathrm{Al}-\mathrm{HQ}$ in the $\mathrm{KCl}$ extracts and that in the soil solution compared with the $\mathrm{CaCl}_{2}$ and $\mathrm{LaCl}_{3}$ suggests $\mathrm{KCl}$ at the ionic strength of the soil solution is more representative of the concentration of toxic $\mathrm{Al}$ in the soil solution. This may be important when comparing soils which differ markedly in exchangeable $\mathrm{Al}$.

The proportion of Al-tot that reacted with $8-\mathrm{HQ}$ in $15 \mathrm{sec}$. increased with the charge of the extracting cation, possibly because the ability of the cation to displace $\mathrm{Al}$ from organic complexes also increased with charge. For example, in an hypothetical solution containing $50 \mu M$ of both $\mathrm{Al}$ and citrate (which has a similar affinity for $\mathrm{Al}$ as humic acid, Ritchie et al., 1988), the concen- 
tration of $\mathrm{Al}^{3+}$ at $\mathrm{pH} 4$ may be estimated to be 3,

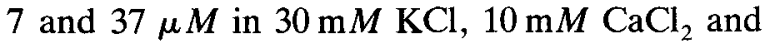
$5 \mathrm{mM} \mathrm{LaCl}$, respectively. Evidence that Al-HQ may be able to distinguish between organically complexed $\mathrm{Al}$ and inorganic monomeric $\mathrm{Al}$ is provided by the differences in the $\mathrm{Al}-\mathrm{HQ}$ concentrations of the soils and how that difference decreased according to the type of extracting cation in the order $\mathrm{KCl}>\mathrm{CaCl}_{2}>\mathrm{LaCl}_{3}$. The $\mathrm{KCl}$ extracts of soil 3 contained a greater proportion of $\mathrm{Al}-\mathrm{HQ}$ than the $\mathrm{KCl}$ extracts of soils 1 and 2, whereas there was no difference between the soils in the proportion of $\mathrm{Al}-\mathrm{HQ}$ in the $\mathrm{LaCl}_{3}$ extracts. The implication that there was less soluble organically complexed $\mathrm{Al}$ in soil 3 is consistent with the lower UV absorbance of its soil solution in comparison to soils 1 and 2 .

\section{Acknowledgements}

This work was funded by the Australian Wool Corporation. We are indebted to Ms D Cawley for assistance during all stages of the experimental and analytical work. We wish to thank Mr S J Carr for providing soil, Dr W M Porter who suggested locations for soil collection and Mr B J Scott for assistance with Genstat 5 and general discussion.

\section{References}

Abacus Concepts Inc. 1988 Statview v 1.03. Abacus Concepts Inc., 1984 Bonita Ave., Berkeley, CA.

Adams F and Hathcock P J 1984 Aluminium toxicity and calcium deficiency in acid subsoil horizons of two coastal plains soil series. Soil Sci. Soc. Am. J. 48, 1305-1309.

Blamey F P C, Edwards D G and Asher C J 1983 Effects of aluminium, $\mathrm{OH}: \mathrm{Al}$ and $\mathrm{P}: \mathrm{Al}$ molar ratios, and ionic strength on soybean root elongation in solution culture. Soil Sci. 136, 197-207.

Cameron R S, Ritchie G S P and Robson A D 1986 Relative toxicities of inorganic aluminium complexes to barley. Soil Sci. Soc. Am. J. 50, 1231-1236.

Castellan G W 1970 Physical Chemistry. Addison-Wesley, Reading, MA.

Conyers M K and Scott B J 1989 The influence of surface incorporated lime on subsurface soil acidity. Aust. J. Exp. Agric. 29, 201-207.

Coventry D R and Evans J 1989 Symbiotic nitrogen fixation and soil acidity. In Soil Acidity and Plant Growth. Ed. A D Robson. pp 103-137. Academic Press, Australia.

Dougan W K and Wilson A L 1974 The absorptiometric determination of aluminium in water. A comparison of some chromogenic reagents and the development of an improved method. Analyst 99, 413-430.

Gillman G P 1976 A centrifuge method for obtaining soil solution. CSIRO Aust. Div. Soils, Div. Rep. No. 16.

Gillman G P and Bell L C 1978 Soil solution studies on weathered soils from tropical North Queensland. Aust. J. Soil Res. 16, 67-77.

Hanson W C 1950 The photometric determination of phosphorus in fertilizers using the phosphovanadomolybdate complex. J. Sci. Food Agric. 1, 172-173.

Hue N V, Craddock G R and Adams F 1986 Effect of organic acids on aluminium toxicity in subsoils. Soil Sci. Soc. Am. J. $50,28-34$.

James B R, Clarke C J and Riha S J 1983 An 8-hydroxyquinoline method for labile and total aluminium in soil extracts. Soil Sci. Soc. Am. J. 47, 893-897.

John M K 1970 Colorimetric determination of phosphorus in soil and plant materials with ascorbic acid. Soil Science $109,214-220$.

Johnson C M and Ulrich A 1959 Analytical methods for use in plant analysis. Calif. Agric. Exp. Stn. Bull. No. 766.

Kerven G L, Edwards D G, Asher C J, Hallman P S and Kokot $S$ 1989a Aluminium determination in soil solution. I. Evaluation of existing colorimetric and separation methods for the determination of inorganic monomeric aluminium in the presence of organic acid ligands. Aust. J. Soil Res. 27, 79-90.

Kerven G L, Edwards D G, Asher C J, Hallman P S and Kokot S 1989 b Aluminium determination in soil solution. II. Short term colorimetric procedures for measurement of inorganic monomeric aluminium in the presence of organic acid ligands. Aust. J. Soil Res. 27, 91-102.

Kim M K, Asher C J, Edwards D G and Date R A 1985a Aluminium toxicity: Effects on growth and nodulation of subterranean clover. Proc. of the XV Intern. Grasslands Conference.

Kim M K, Edwards D G and Asher C J 1985b Tolerance of Trifolium subterraneum cultivars to low $\mathrm{pH}$. Aust. J. Agric. Res. 36, 569-78.

McLaughlin M J and James T R 1989 The effect of subsurface aluminium on the growth and uptake of surfaceapplied phosphorus by wheat seedlings. J. Plant Nutr. 12, 603-620.

McLaughlin M J, Baker T G, James T R and Rundle $\mathbf{J}$ A 1990 Distribution and forms of phosphorus and aluminium in acidic topsoils under pastures in south-eastern Australia. Aust. J. Soil Res. 28, 371-385.

Munns D N 1965 Soil acidity and growth of a legume. II. Reactions of aluminium and phosphate in solution and effects of aluminium, calcium and $\mathrm{pH}$ on Medicago sativa L. and Trifolium subterraneum $\mathrm{L}$. in solution culture. Aust. J. Agric. Res. 16, 743-755.

Noble A D, Sumner M E and Alva A K 1988 Comparison of aluminon and 8-hydroxyquinoline in the presence of fluoride for assaying phytotoxic aluminium. Soil Sci. Soc. Am. J. 52, 1059-1063.

Ritchie G S P, Nelson M P and Whitten M G 1988 The estimation of free aluminium and the competition between fluoride and humate anions for aluminium. Comm. Soil Sci. Plant Anal. 19, 857-871. 
Robson A D and Loneragan J F 1970 Nodulation and growth of Medicago truncatula on acid soils. 1. Effect of calcium carbonate and inoculation level on the nodulation of Medicago truncatula on a moderately acid soil. Aust. J. Agric. Res. 21, 427-434.

Rothamsted Statistics Department 1987 Genstat 5 release 1.2. Rothamsted Experimental Station, Harpenden, Hertfordshire, U.K.

Tan K H and Binger A 1986 Effect of humic acid on aluminium toxicity in corn plants. Soil Science. 141, 20-25.

Uren N C 1989 Rhizosphere reactions of aluminium and manganese. J. Plant Nutr. 12, 173-185.

Whitten M G and Ritchie G S P 1991 Soil Tests for Aluminium Toxicity in the Presence of Organic Matter:
Laboratory Development and Assessment. Comm. Soil Sci. Plant Anal. 22 (In press).

Williams C H 1980 Soil acidification under clover pasture. Aust. J. Exp. Agric. Anim. Husb. 20, 561-567.

Wright R J and Wright S F 1987 Effects of aluminium and calcium on the growth of subterranean clover in Appalachian soils. Soil Science 143, 341-348.

Wright R J, Baligar V C and Wright S F 1987 Estimation of phytotoxic aluminium in soil solution using three spectrophotometric methods. Soil Science 144, 224-232.

Yeomans J C and Bremner J M 1988 A rapid and precise method for routine determination of organic carbon in soil. Comm. Soil Sci. Plant Anal. 19, 1467-1476. 